\title{
Potential Use of Mobile Devices in Selected Public Senior High Schools in the City of Manila Philippines
}

\author{
Wan Jin and Cecilia Junio-Sabio \\ De La Salle Araneta University \\ Metro Manila, Philippines
}

\begin{abstract}
As mobile devices become more affordable, sustainable and portable, they have become kinds of personal ecosystem to people in the 21 st century, and they bring unprecedented educational opportunities to students of all socio-economic levels. This research explored the potential use of mobile devices in selected public senior high schools in the City of Manila, Philippines. A total of 152 students from a couple of schools have participated in this study. It was found that the majority of the participants have some form of mobile devices and internet access as they were used for a variety of learning activities outside the classroom settings. However, substantial digital inequalities also exist among public schools in the City of Manila. Overall, the findings indicate that mobile devices have shown potential to be adopted in existing public senior high schools, and there is a need to update policy and curricula to respond to the mobile era.
\end{abstract}

Keywords: mobile devices, educational technology, senior high school, public school, Manila Philippines

\section{Introduction}

As times change and knowledge of man becomes more advanced, digital and mobile technologies are "changing job profiles and skills, while offering possibilities for accelerated learning" (The World Bank Group, 2011, p.7). Mobile devices like smartphones, tablets or e-readers provide users with access to broader and more flexible source of information and learning resources aroundthe-clock from any location (Ally, Grimus, \& Ebner, 2014), offer people with diversified opportunities for innovative, proactive, and affective learning (Seifert, 2016), and provide students with the skills and competencies critical for success in the 21st century (World Economic Forum, 2015). Not surprisingly, learning with mobile devices become widespread globally, and will eventually integrated with mainstream education in the near future (UNESCO, 2013). 
Currently, as mobile devices become more affordable, sustainable and portable, people in developing countries have more of these expedients than computers or laptops (Ally, Grimus, \& Ebner, 2014). Mobile devices do not only require substantially less infrastructure and much prevalent than laptop or desktop, but also necessitates its infrastructure, hardware, software and systems are improving and decreasing (Ally, Grimus, \& Ebner, 2014). In addition, the ownership of mobile devices is accessible by people from different socioeconomic class. As a result, many education experts believe that a better way to integrate the power of technology to support students' learning in the developing world is through the use of mobile devices rather than laptops or computers (Miyazawa, 2009; Trucano, 2009; UNESCO, 2013).

The adoption of educational technologies in the secondary education in the Philippines has not been very successful due to the poor quality of infrastructure, shortage of capable teachers and lack of effective guidance. Many schools in the country have remained stuck in the industrial age and are incessantly falling behind in the digital age. However, as one of the youngest demographics in the region of Asia (GSMA Intelligence, 2014) and one of the fastest growing mobile devices markets in South East Asia (GSMA Intelligence, 2014), mobile devices are becoming ideal technology-enabled tools that supports young Filipinos to become more digitally connected and continuously exposed to information and knowledge. In Jun 2017, the enrolment of the first batch of Grade 12 students marked the full implementation of the two-year senior high school program in the Philippines' educational system. Ideally, the use of mobile technology may help to ensure access to senior high school's education for all, encourage more young people to alternative learning pathways, as well as prepare them to effectively respond to MOOCs (Massive Open Online Courses), which is the latest trend and long-term strategy for many top-tier higher educational institutes. As a large young populations, high mobile engagement, large proportion of English speakers, rapidly growing internet penetration, the Philippines seems ready to adopt the mobile devices into the educational field. As among the last three countries in the world to implement $\mathrm{K}$ to 12 , it is significant to conduct an up-to-date research that focused on the use of mobile devices for academic activities. It must be recalled that the country started implementing $\mathrm{K}$ to 12 only in the year 2016-2017 and the first batch of graduate for Grade 12 will be in the year 2017 and 2018.

This research specifically considered two publicly funded schools in the City of Manila, namely University of the City of Manila Senior High School and Romon Avanceńa High School. University of the City of Manila is the first City University in the Philippines, which is funded by the local government of Manila. In school year 2016-2017, it considered offering Senior High School program under the leadership of one of the author (Dr. Cecilia Junio-Sabio) to help the Division of City School (DCS) of Manila accommodate some high school students which at that time totaled to more than 50,000 students coming from various public high schools in the City. As a higher education institution operating under the supervision of the Commission on Higher Education (CHED), it sought approval to offer Senior High School (SHS) program from the 
Department of Education in 2015. In the year 2016-2017, it accommodated more than 1,500 students which enrolled in different specializations or tracks such as (1) Science, Technology, Engineering and Mathematics (STEM); (2) Accountancy, Business and Management (ABM) and (3) Humanities and Social Sciences (HUMSS). Another school that considered in this research is Romon Avancena High School which also offered Senior High School (SHS). The school is named after Romon Avanceńa who used to be the Chief Justice of the Supreme Court of the Philippines during 1925 to 1941. As one of the public schools in the City of Manila, Romon Avanceńa High School falls under the supervision of the Division of City Schools of Manila (DCS). Aside from offerings senior high school programs like STEM, ABM, and HUMSS, this school also offers General Academic Stand (GAS). Besides, as one of the Districts in the Secondary Education Institution in the City of Manila, Romon Avanceńa High School offers Technical-Vocational-Livelihood (TVL) for senior high school students. With prominent and diverse specializations in secondary education, the researchers considered Romon Avanceńa High School as one of the subjects of this research because the said school has maintained certain standards of teaching and discipline as evidenced by the complete senior high school programs they are offering. Similarly, University of the City of Manila Senior High School was considered because of its excellence in higher education which commitment to providing access to education was extended up to the provision of Senior High School when the City was seeking assistance from higher education institutions (HEIs) to help provide SHS.

The purpose of this study is to explore the potential use of mobile devices in public senior high schools in the City of Manila, the Philippines. Researchers believe that "the student's point of view on the subject of mobile technology is extremely valuable as many students are native users of mobile technology for many reasons" (Laskin \& Avena, 2015, p.278). Liu, Han and Li (2010) also pointed out that "the key issues for success of using mobile devices for learning lies in an individual's subjective willingness and cognitive engagement" (p.220). To understand students' experiences and perception toward the use of mobile devices for learning purpose in their daily life is a key step to identify the potential use of mobile devices in selected public schools in the City of Manila Philippines. The findings of this research will eventually provide teaching staffs, school administrators, and policy makers the opportunity to find the potential use of mobile devices within the existing public senior high school context in the Philippines, as well as encourage them to unlock the enthusiasm and creativity of today's digital natives.

\section{Methodology}

This study utilized the descriptive type of research with mixed method approach. A previous research was done by Jin, Prudente and Aguja (2018) on the students' experiences and perceptions on the use of mobile devices for learning. Their respondents however were senior high school students from the selected private schools in Metro Manila. Given several challenges in operating publicly funded Senior High School institutions, the researchers deems it necessary to conduct a similar research whose respondents are senior high 
school students from public institutions. The research instrument utilized in this research is a questionnaire. Specifically, this study surveyed two public senior high schools in the City of Manila Philippines, namely, University of the City of Manila Senior High School and Romon Avancena High School. The surveys were distributed by hand in the classroom with the help of school administrators, faculties, and students completed the survey on a voluntary basis. A total of 160 students from the selected public senior high schools were randomly invited to participate in a survey questionnaire, and 152 participants successfully answered with a response rate of $95 \%$.

The questionnaire consisted of four sections which are: Part I of the questionnaire focused on the rates of mobile devices' ownership and internet access among public senior high school students; Part II determines the regularity of using mobile gadgets with internet access for academic activities both inside and outside the classroom; Part III assesses the students' perception on the helpfulness of mobile devices to their learning purposes; and Part IV explores the students' opinions on the use of mobile devices if it should be allowed inside the classroom or otherwise. Aside from the questionnaires, informal interviews and classroom observations were also carried out in this research. It were primarily intended to triangulate the participants' data, as well as reveal more detailed insights which would have been impossible to discover if the data gathering is limited in the use of the questionnaire.

\section{Results}

Examining the ownership of mobile devices among students had a significant contribution in accomplishing the purpose of this research. Table 1 shows the ownership of mobile devices among the participants in the selected public schools.

Table 1: What type(s) of mobile device(s) do you own?

\begin{tabular}{|c|c|c|c|c|c|c|}
\hline & \multicolumn{2}{|c|}{$\begin{array}{c}\text { University of the } \\
\text { City of Manila Senior } \\
\text { High School }\end{array}$} & \multicolumn{2}{|c|}{$\begin{array}{c}\text { 2omon Avanceńa } \\
\text { High School }\end{array}$} & \multicolumn{2}{|c|}{ TOTAL } \\
\cline { 2 - 7 } & Number & Frequency & Number & Frequency & Number & Frequency \\
\hline Smartphone & 96 & $91 \%$ & 25 & $54 \%$ & 121 & $80 \%$ \\
\hline $\begin{array}{c}\text { Basic } \\
\text { Mobile } \\
\text { Phone }\end{array}$ & 11 & $10 \%$ & 19 & $41 \%$ & 30 & $20 \%$ \\
\hline Tablet & 17 & $16 \%$ & 1 & $2 \%$ & 18 & $12 \%$ \\
\hline E-reader & 2 & $2 \%$ & 0 & $0 \%$ & 2 & $1 \%$ \\
\hline None & 2 & $2 \%$ & 1 & $2 \%$ & 3 & $2 \%$ \\
\hline
\end{tabular}

Apparently, the participants in both of the public senior high schools shown impressive ownership of mobile devices: $98 \%$ of the sample space owned at least one mobile device. Specifically, $80 \%$ of them claim ownership of a smartphone, followed by a $20 \%$ ownership of basic mobile phone, $12 \%$ tablet ownership, and $1 \%$ e-reader ownership. Although the researchers believe that an enormous concern about the use of mobile devices in the classroom setting is ensuring 
every students can access on device (UNESCO, 2013), it seems that the selected public schools in Manila City have huge potential to achieve one device to one user access due to students' current use of the mobile devices. Too often, developing countries like the Philippines falls behind the developed world in terms of educational technologies, the rapid growth of mobile devices suggests that this trends might be change. As the mobile devices becomes portable and affordable as educational tools, a better way to pursuing educational technology for public senior high schools in the Philippines is through mobile devices rather than desktop or laptop.

However, it is important to note that there are striking differences in the types of mobile device ownership between the two selected public senior high schools in Manila City, where 54\% of respondents from Romon Avanceńa High School own a smartphone, compared with $91 \%$ of respondents from University of the City of Manila Senior High School. Besides, $41 \%$ of participants from Romon Avanceńa High School own a basic mobile phone, compared with only $10 \%$ of respondents from University of the City of Manila Senior High School. The differences could be due to families' income since Romon Avanceńa High School is located at a comparatively poorer community. Overall, although mobile devices are owned by a vast majority of respondents in this research, not all mobile devices have the same capabilities and are able to provide the same kinds of learning experiences for students in the selected public senior high schools in the Manila City. In addition, the ownership of mobile devices will not guarantee their effectiveness for the performance of learning (Liu, Han, \& Li, 2010). Ideas on ways of how it can be able to support learning and education in more complete and meaningful ways should be carefully thought of in order to maximize the advantages of mobile devices.

Having established the ownership of mobile devices, it was important to examine the internet connectivity that students often use since network is crucial for the adoption of mobile devices in terms of learning. Table 2 shows that the most popular internet connectivity among respondents was mobile 3G/4G access, with $64 \%$ of them using it at oftentimes, followed by home broadband access $(50 \%)$, public available Wi-Fi access (19\%), and school access $(9 \%)$. Only $2 \%$ of the respondents claim that they have no internet connectivity.

Results indicate that the access to the internet connectivity is widespread among the respondents in selected public senior high school. However, students seem hardly connecting internet in the formal educational settings and access frequently outside the school. Essentially, unlike Romon Avanceńa High School, University of the City of Manila Senior High School offers Wi-Fi access for students, however, not all participants prefer to utilize it. The possible reason behind this could be the teachers' regulation that mobile devices are not allowed during lessons.

Moreover, the results resulted that the respondents in the two selected public senior high schools connect to the internet very differently: the most popular internet connectivity among respondents from Romon Avanceńa High School 
was mobile 3G/4G access (65\%), followed by public available Wi-Fi access (24\%), and home broadband access (13\%). However, for the respondents studying in the University of the City of Manila Senior High School, the most used internet connectivity was home broadband access $(66 \%)$, followed by mobile 3G/4G access (58\%), public available Wi-Fi access $(17 \%)$, and school access $(12 \%)$. Apparently, students from Romon Avanceńa High School face more limitations and difficulty in getting enough opportunities for internet connections, especially in the forms of home broadband access and school access.

Table 2: What type(s) of internet access do you often use?

\begin{tabular}{|c|c|c|c|c|c|c|}
\hline & \multicolumn{2}{|c|}{$\begin{array}{c}\text { University of the } \\
\text { City of Manila Senior } \\
\text { High School }\end{array}$} & \multicolumn{2}{|c|}{$\begin{array}{r}\text { Romon Avanceńa } \\
\text { High School }\end{array}$} & \multicolumn{2}{|c|}{ TOTAL } \\
\cline { 2 - 7 } & Number & Frequency & Number & Frequency & Number & Frequency \\
\hline $\begin{array}{c}\text { Mobile } \\
\text { 3G/4G } \\
\text { Access }\end{array}$ & 67 & $58 \%$ & 30 & $65 \%$ & 97 & $64 \%$ \\
\hline $\begin{array}{c}\text { Home } \\
\text { Broadband } \\
\text { Access }\end{array}$ & 70 & $66 \%$ & 6 & $13 \%$ & 76 & $50 \%$ \\
\hline $\begin{array}{c}\text { Public } \\
\text { Available } \\
\text { Wi-Fi } \\
\text { Access }\end{array}$ & 18 & $17 \%$ & 11 & $24 \%$ & 29 & $19 \%$ \\
\hline $\begin{array}{c}\text { School } \\
\text { Access }\end{array}$ & 13 & $12 \%$ & 0 & $0 \%$ & 13 & $9 \%$ \\
\hline None & 2 & $2 \%$ & 0 & $0 \%$ & 2 & $2 \%$ \\
\hline
\end{tabular}

Internet and wireless technology dramatically spreading information and knowledge timely and support learning virtually anywhere and anytime (Dogruer, Eyyam \& Menevis, 2011). Given this, students with very limited internet connectivity are significantly disadvantaged in accessing and discovering meaningful ways for academic activities. As a result, planning and strategies may be needed from the Department of Education (DepEd) and the Department of Information Communications Technology (DICT) to make internet connectivity becoming accessible in terms of cost for public high schools in the Philippines as it is vitally important to encourage students in the 21st Century to use this invaluable source to systematically maximize use of online resources in their academic activities.

Table 3 shows students' regularity of using mobile gadgets with internet access for academic purposes both inside and outside the classroom. Among all participants in the selected schools, nearly eight in ten (78\%) go online with mobile devices for learning purposes every day, $16 \%$ use it on a weekly basis, $1 \%$ on a monthly basis, and 3\% use it over monthly. Only $2 \%$ of the participants report that they have never used mobile devices with internet for the purpose of learning. 
Not surprisingly, most of the participants in the selected public senior high schools have used mobile devices with internet for their academic activities in a daily basis. However, the potential use of mobile devices with internet in a seamless learning scenario seems unnoticed yet by them due to the previous findings that participants rarely use or have no internet connection at school. Moreover, the results indicate that students from Romon Avanceńa High School are use mobile devices with internet for learning activities less frequently than students from University of the City of Manila Senior High School. The possible reasons behind this could be the capabilities of mobile devices they are able to access, as well as the opportunity towards and quality of internet connections.

Table 3: How often do you use mobile device(s) with internet for learning purpose?

\begin{tabular}{|c|c|c|c|c|c|c|}
\hline & \multicolumn{2}{|c|}{$\begin{array}{c}\text { University of the } \\
\text { City of Manila Senior } \\
\text { High School }\end{array}$} & \multicolumn{2}{|c|}{$\begin{array}{c}\text { Romon Avanceńa } \\
\text { High School }\end{array}$} & \multicolumn{2}{|c|}{ TOTAL } \\
\cline { 2 - 7 } & Number & Frequency & Number & Frequency & Number & Frequency \\
\hline Daily & 92 & $87 \%$ & 26 & $57 \%$ & 118 & $78 \%$ \\
\hline Weekly & 9 & $8 \%$ & 16 & $35 \%$ & 25 & $16 \%$ \\
\hline Monthly & 1 & $1 \%$ & 1 & $2 \%$ & 2 & $1 \%$ \\
\hline $\begin{array}{c}\text { Over } \\
\text { Monthly }\end{array}$ & 3 & $3 \%$ & 1 & $2 \%$ & 4 & $3 \%$ \\
\hline Not Used & 1 & $1 \%$ & 2 & $4 \%$ & 13 & $2 \%$ \\
\hline
\end{tabular}

Numerous experts believe that by using mobile devices with internet, the learner is communicative, and the learning is interactive while occurring in multiple contexts. As a result, the gap between formal and informal learning seems to become less relevant (UNESCO, 2013; Sharples, 2013). Therefore, it is important for the Department of Education to address how to systematically maximize use of mobile devices with internet for academic activities both inside and outside the classroom since the majority of participants in the selected public senior high schools were using it in their everyday life.

Based on the respondents' answers as seen in Table 4, many of them found meaningful practices for their learning by using mobile devices: with $64 \%$ of them agreeing that it is indeed useful, $31 \%$ feeling little advantages, $2 \%$ feeling it barely beneficial, and only $3 \%$ said that mobile devices can be beneficial for the participants' performance of learning and enhance their learning outcomes.

Table 4: How much do you think mobile device(s) help your learning?

\begin{tabular}{|c|c|c|c|c|c|c|}
\hline & \multicolumn{2}{|c|}{$\begin{array}{c}\text { University of the } \\
\text { City of Manila Senior } \\
\text { High School }\end{array}$} & \multicolumn{2}{|c|}{$\begin{array}{c}\text { Romon Avanceńa } \\
\text { High School }\end{array}$} & \multicolumn{2}{|c|}{ TOTAL } \\
\hline & Number & Frequency & Number & Frequency & Number & Frequency \\
\hline A lot & 73 & $69 \%$ & 25 & $54 \%$ & 98 & $64 \%$ \\
\hline Little & 31 & $29 \%$ & 15 & $33 \%$ & 46 & $31 \%$ \\
\hline Barely & 1 & $1 \%$ & 2 & $4 \%$ & 3 & $2 \%$ \\
\hline $\begin{array}{l}\text { Not } \\
\text { at all }\end{array}$ & 1 & $1 \%$ & 4 & $9 \%$ & 5 & $3 \%$ \\
\hline
\end{tabular}




\begin{tabular}{|c|c|c|c|c|c|c|}
\hline $\begin{array}{c}\text { I have } \\
\text { no } \\
\text { idea }\end{array}$ & 0 & $0 \%$ & 0 & $0 \%$ & 0 & $0 \%$ \\
\hline
\end{tabular}

However, it seems that these young Filipino have only active and enthusiastic using mobile devices for informal learning activities since the selected public senior schools do not allow students to use mobile devices during class hour. It can be deduced therefore, based on the observation made on this research, the previous findings indicate that students rarely use or have no internet connection at school. Differences between the two selected public high schools in this part are not striking, other than the fact that there are more participants from Romon Avanceńa High School who believe that mobile devices do not help in their learning completely. The possible reasons behind this could be the digital inequality, especially in terms of internet connection since "being underconnected means that critical opportunities to develop creative projects, take advantage of educational media, explore extracurricular programs, and complete homework, are limited" (Rideout \& Katz, 2016, p.40).

As people in the 21st Century fell quite natural for the digital environment, young Filipino shall finally living and learning in an "always connected" digitalbased society. With a growing number of participants have positive attitudes towards the adoption of mobile devices for informal learning activities, it is important for the faculty staff, school administrators, and policy makers to recognize the need for adopting mobile devices and linking internet to formal educational settings. After all, "schools as the primary, traditional distributors of skill-sets necessary for successful citizens must adopt to a changing world" (Shippee \& Keengwe, 2014, p.104).

Indeed, today's young Filipinos are the first generation who grown up surrounded by technology - they are found to be multi-taskers, screen readers, social media users, and digital gamers. Educational institutions should create relevant learning experiences in the classroom setting that mirror their daily lives and the reality of the future society. However, based on the researchers' observation in the two selected public senior high schools, students are generally banned to use their mobile devices in the formal classroom setting. Table 5 then shows the participants' perceptions on whether mobile devices should be allowed to use in the classroom settings.

Table 5 Do you think mobile device(s) should be allowed in the classroom?

\begin{tabular}{|c|c|c|c|c|c|c|}
\hline \multirow{2}{*}{} & \multicolumn{2}{|c|}{$\begin{array}{c}\text { University of the } \\
\text { City of Manila Senior } \\
\text { High School }\end{array}$} & \multicolumn{2}{|c|}{$\begin{array}{c}\text { Romon Avanceńa } \\
\text { High School }\end{array}$} & \multicolumn{2}{|c|}{ TOTAL } \\
\cline { 2 - 7 } & Number & Frequency & Number & Frequency & Number & Frequency \\
\hline Yes & 77 & $73 \%$ & 16 & $35 \%$ & 93 & $61 \%$ \\
\hline No & 14 & $13 \%$ & 18 & $39 \%$ & 32 & $21 \%$ \\
\hline $\begin{array}{c}\text { Not } \\
\text { sure }\end{array}$ & 15 & $14 \%$ & 12 & $26 \%$ & 27 & $18 \%$ \\
\hline
\end{tabular}


Not surprisingly, many of the participants expressed a belief that mobile devices should be allowed to use during class (61\%), $18 \%$ of the participants are not sure about it, and around one-fifth (21\%) of the participants expressed negative attitudes to the adoption of mobile devices inside classroom. Furthermore, there are significant differences between the selected public high schools in terms of whether mobile devices should be allowed inside the classroom or not students from Romon Avanceńa High School hold less positive attitudes in its implementation compared to the students from the University of the City of Manila Senior High School.

Participants who hold positive attitude towards the implementation of mobile devices in the classroom setting gave the following reasons:

1. "Mobile devices gives more importance to the learning of the students and it allows the student to work for their projects, assignments, or other paper works easily, thus, it should be allowed in the classroom";

2. "It will serve as a secondary learning (pathway) despite the students not having to understand the lecture";

3. "It can provide additional knowledge that the book is not able to deliver. Also, it can be utilized as a learning material";

4. "The internet has everything and it helps us to learn more things and acquire supplementary knowledge";

5. "Some of the lectures can be easily grasped through the use of the camera equipped in the phone".

Furthermore, the participants believe that mobile devices have shaped and educated this generation of young pupils, and school should transport 21st Century technology upon learning as it helps the students in various consequential ways. For example, students from both schools specifically reasoned out the following:

1. "By allowing those mobile devices in the classroom, the students will be more comfortable (with the learning environment) and well-off in their lessons";

2. "Its use will be able to enhance the enthusiasm of each student to learn more in a different way";

3. "It is with the reason that we are now in the 21st Century where the digital age takes place";

4. "Indeed, this generation is a more technologically inclined and advanced".

In addition, reduced expenditures can be a reason for the support of mobile devices if its use shall be implemented in the classroom. For example, one of the participants pointed out that "Some students cannot afford expensive books, therefore by using mobile devices, they can easily access information". Interestingly, some participants also highlight that mobile devices should be allowed if used in an appropriately during classroom hours - "It will be a more helpful tool in studying rather than the book if only under the condition that it will be used in a scholarly manner". 
Participants who hold neutral attitude towards the implementation of mobile devices in the classroom setting gave the following reasons:

1. "Mobile device is somehow helpful to students regarding to learning purposes. Everything is in there, but I don't think that all of those are reliable sources. Instead, citing on tangible books must be practiced because it's a hundred percent reliable than mobile devices";

2. "Some of the teachers do not allow the use of mobile devices during class hours";

3. "Although students won't have to bring a lot of books and notebooks (to school) everyday, some students cannot afford to buy gadgets";

4. "It depends, because some students cannot focus on their lessons".

Apparently, these participants have somehow clearly recognized the influence of mobile devices upon its implementation in the formal education settings, may they be in a positive approach or a negative way.

Participants who hold negative attitude towards the implementation of mobile devices in the classroom setting gave the following reasons:

1. "Many students use these not for educational purposes, but for their own purpose, but for their own entertainment and pleasure. They tend to use their social media accounts while having class. It is not helpful for them as well as to the teachers";

2. "The students will not be able to focus during discussion as they are inclined to playing games or use mobile devices for Facebook";

3. "The lectures will be for our benefits and will be more educational-friendly than devices";

4. "As part of the rules and regulations, the implementation of the use of mobile devices during class hours should not be followed".

All in all, distraction and by-laws were two main reasons mostly mentioned by the participants in terms of the adoption of mobile devices in the classroom setting.

Despite widespread enthusiasm, it is important to note that in the context of implementing mobile devices for learning, the learners are trusted with great self-management and autonomy, and learners with a higher level of selfdiscipline tend to more effectively engage in the mobile devices learning context (Wang, Wu, \& Wang, 2009). Thus, the individuals' subjective willingness and cognitive engagement might be the key issues for students to successfully adopt mobile devices for their learning. Moreover, the implementation of mobile devices in the classroom setting should also be parallel with the school leaders' understanding, as well as teachers' professional development, in order to improve teachers' teaching with mobile devices, as well as formulate and adopt an updated pedagogy for innovative, proactive, and effective learning. 


\section{Discussion}

Learning with mobile devices is a relatively new phenomenon in the Philippines basic education system, and the Department of Education's policies that focused on ICT were developed in the pre-mobile era. In order to make mobile devices viable in the Philippines' senior high school context, it is very important for education leaders, policymakers, and school administrators to have the courage to make an innovation and difference at the start-up of senior high school education in the Philippines. Specifically, such policies must include the support in bringing about meaningful mobile devices integration in the areas of teaching and learning and increase its scale, to help educators develop innovative methodologies and appropriate pedagogies for the use of mobile devices, design of guidelines for schools planning to implement mobile devices into the curriculum. Without this courage, the young generation of the Philippines will miss an enormous opportunity made possible by the advent of mobile devices while other developing nations undoubtedly seize it. For example, Kenya has launched a mobile-empowered curriculum named the power of mLearning project. This curriculum is delivered through $3 \mathrm{G}$ enabled tablet to make learning more interactive, interesting and locally relevant. Another example could find in Amman, Jordan. The project, Personalized learning via 3G in Jordanian Schools: Anytime, Anywhere Access to Educational Resources, provide more than 200 students with mobile devices at a ratio of one device per student at two public schools during the 2011 - 2012 academic years, and the students' learning outcomes are very impressive.

Furthermore, it is important to highlight that mobile devices themselves do not add value to education, since "education outcomes are not technology itself, but instead, about how technology is used" (Haßler et al., 2016, p.5). As a result, students in the public schools does not only need gadgets, but also require better teachers in the classroom. In order to ensure widespread and successful program related to mobile devices with internet in the public schools in the Philippines, the Department of Education need to provide teacher training program support with regard to the value of mobile device in teaching and learning processes, so that these will be help improved their teaching, as well as the formulation and adoption of an updated pedagogy.

\section{Conclusion}

Mobile devices are indeed changing both what is learned and the ongoing process of learning. Although there are a lot of successful projects for the implementation of mobile devices in school settings worldwide, it is very significant for local educators to identify how these projects of one situation can be trustworthy and useful for their own context. This research explored the potential use of mobile devices in the selected public schools in the city of Manila Philippines. Upon looking and analyzing the results, it can be observed that majority of the participants in selected public senior high schools have discovered meaningful ways of using mobile devices for a variety of academic activities outside the classroom settings. However, substantial digital inequalities still exist among public students, and the use of mobile devices for learning is uneven through the public schools in the city of Manila. Some 
scenarios that can add proof to this firstly, some schools do not have internet and wireless capabilities; many teachers are not ready to integrate mobile devices with internet during discussion; the city government does not have enough funding to support the reform and expansion of educational technology. Apparently, public schools in the Philippines have very diverse needs in terms of evaluate, support, and guidance since they are at different stages of their record towards the integration of mobile devices for academic activities, and a one-size-fits-all approach will not achieve success in the context of the City of Manila, the Philippines.

Too often, the developing world falls behind the developed world in terms of educational technologies and the basic education in the developing world has generally remained stuck in the industrial age and falling behind in the digital age. However, with the increasingly expanding use of mobile devices among young generations and the implementation of $\mathrm{K}$ to 12 education in the Philippines in 2017, this trend might have a chance to change dramatically the country's educational outcomes. The primary limitation of this research was the sample which was taken from only two selected public school in Manila City. This limitation presents an opportunity to use larger samples in other cities or provinces and different research designs to validate the results of the study.

\section{References}

Ally, M., Grimus, M., \& Ebner, M. (2014). Preparing teachers for a mobile world, to improve access to education. Prospects, 44, 43-59. http://doi.org/10.1007/s11125-014-9293-2

Eyyam, R., Meneviş,I., \& Doğruer, N. (2010). Perceptions of prospective teachers towards technology use in class. Procedia-Social and Behavioral Sciences, 3, 88-93. http://doi.org/10.1016/j.sbspro.2010.07.016

GSMA Intelligence. (2014). Country overview: Philippines growth through innovation. Retrieved from https://www.gsmaintelligence.com/research/?file=141201philippines.pdf\&download

Haßler, B., Major, L., Warwick, P., Watson, S., Hennessy, S., \& Nicholl, B. (2016). Perspectives on Technology, Resources and Learning: Productive Classroom Practices, Effective Teacher Professional Development. University of Cambridge. Retrieved from

https://www.educ.cam.ac.uk/people/staff/watson/Hassler\%20et\%20al\%20201 $6 \% 20-$

\%20Perspectives\%20on\%20Technology, \%20Resources\%20and \%20Learning\%20(F ull).pdf

Jin, W., Prudente, M., Aguja, S. (2018). Students' experiences and perceptions on the use of mobile devices for learning. Advanced Science Letters, American Scientific Publishers (in press).

Laskin, A., \& Avena, J. (2015). Introduction of mobile media into formal classroom learning environments. Journalism \& Mass Communication Educator, 70(3), 276285. https:// doi.org/10.1177/1077695815601170

Liu, Y., Han, S., \& Li, H. (2010). Understanding the factors driving m-learning adoption: A literature review. Campus-Wide Information Systems, 27(4), 210-226. https://doi.org/10.1108/10650741011073761

Miyazawa, I. (2009). Literacy promotion through mobile phones. The 13th UNESCO-APEID International Conference and World Bank-KERIS High Level Seminar on ICT in Education Project Briefing Paper. Retrieved from 
http://www.unesco.org.pk/education/documents/Project\%20Brief\%20Paper_I CT.pdf

Rideout, V., Katz, V. (2016). Opportunity for all? - Technology and Learning in Lower-income Families. In Joan Ganz Cooney Center at Sesame Workshop. 1900 Broadway, New York, NY. 10023. Retrieved from http://www.joanganzcooneycenter.org/wpcontent/uploads/2016/01/igcc_opportunityforall.pdf

Seifert, T. (2016). Patterns of mobile technology use in teaching: the teacher perspective. I-manager's Journal of Educational Technology, 13(3), 1-17. Retrieved from https://search.proquest.com/openview/897c7249aacc4fea87efd06234c1cd6a/1? pq-origsite $=$ gscholar\&cbl $=2030628$

Sharples, M. (2013). Mobile learning: research, practice and challenges. Distance Education in China, 3(5), 5-11.

Shippee, M., \& Keengwe, J. (2014). mLearning: Anytime, anywhere learning transcending the boundaries of the educational box. Education and Information Technologies, 19(1), 103-113. https:// doi.org/10.1007/s10639-012-9211-2

The World Bank. (2011). Learning for all: investing in people's knowledge and skills to promote development. Retrieved from http://siteresources.worldbank.org/EDUCATION/Resources/ESSU/4632921306181142935/WB_ES_ExectiveSummary_FINAL.pdf

Trucano, M. (2009). Phones are a real alternative to computers. Edutech: A World Bank Blog on ICT in Education. Retrieved from http://edutechdebate.org/mobile-phones-and-computers/phones-are-a-realalternative-to-computers/

UNESCO. (2013). The Future of Mobile Learning: Implications for Policy Makers and Planners. Retrieved from http://unesdoc.unesco.org/images/0021/002196/219637E.pdf

Wang, Y., Wu, M., \& Wang, H. (2009). Investigating the determinants and age and gender differences in the acceptance of mobile learning. British Journal of Educational Technology, 40(1), 92-118. https://doi.org/10.1111/i.14678535.2007.00809.x

World Economic Forum. (2015). New Vision for Education: Unlocking the Potential of Technology. Retrieved from http://www3.weforum.org/docs/WEFUSA_NewVisionforEducation_Report20 $\underline{15 . p d f}$ 